\title{
The linkage between innovation and labour market performance: some empirical evidence from the Nordic region
}

\author{
Svetlana A. Balashova*, and Anastasia A. Abramova \\ Peoples Friendship University of Russia (RUDN University), 6 Miklukho-Maklaya St, 117198 \\ Moscow, Russian Federation
}

\begin{abstract}
It is common knowledge that innovations are the drivers of economic growth. However, the direct relationship between innovation and socio-economic performance is questionable. In the article, we examine the linkage between innovation performance, measured by the Summary innovation index, and labour market indicators in Nordic countries, being the leaders of innovation performance and welfare states at the same time. The study shows that employment is growing among people with higher education with the improvement of innovation performance. At the same time, there is a large share of unemployed among low-skilled workers, which also tends to grow. The causality test analysis between Summary Innovation Index and labour statistics by Granger test for panel data does not reveal the causal relationships.
\end{abstract}

\section{Introduction}

One of the burning topics of the late 20th century and, in particular, of the entire period of the 21 st century is innovation and innovative development. Following the Lisbon Strategy, adopted in 2000, European Union is aimed at achieving global innovation leadership. Each EU country and other European countries have adopted national strategies for innovative development. And although the strategies are not fully implemented and still there are many unsolved issues, the efforts already led to great success, and most European countries are assessed as the top innovatively developed countries in the world. The Nordic countries are highly successful among European countries in terms of innovation performance: Sweden, Denmark and Finland are among the top 10 world leaders. Norway and Iceland are ranked 20 and 21 among 130 countries of the world according to the Global Innovation Index 2020. Moreover, the Nordic countries have the lowest wage inequality and, as a group, the lowest poverty rates, as well as the highest job and life satisfaction. All this is also reflected in the level of innovative development and on working life in general [1].

Innovation strategies, predominantly in high-tech sectors, are attractive and successful in industrialized countries mainly [2]. Firms in such countries invest heavily in R\&D, contributing to economic growth and international trade, focusing on the modernization of production, methods, and processes in traditional sectors of the economy. One of the main

${ }^{*}$ Corresponding author Balashova-sa@rudn.ru 
indicators of achieving the goals of innovative development is the share of R\&D expenditures in the gross domestic product. By increasing spending on $R \& D$, leadership in the technology race should be ensured, the output of high-tech products should increase, and, as a result, the quality of life should improve. In the long term, R\&D spending should support economic growth by increasing productivity and capital. The relationship between innovation capabilities and economic performance are well documented in literature [3].

Innovation development plays a key role in the labour market. On the one hand, new technologies, which are the main features of innovative development, may cause unemployment in the traditional sectors of the economy. On the other hand, these technologies are expected to form high demand in new sectors and even create new sectors [4]. The active introduction of new technologies is causing shifts in employment structure, and wages in some industries can increase significantly [5]. High wages attract highly skilled workers to enterprises. High technology and skilled personnel are expected to increase productivity [6].

The study aims to find empirical evidence that illustrates the relationship between employment growth, the structure of employment and unemployment and the progress in innovative development. We selected the Nordic countries (Denmark, Sweden, Finland, Norway, and Iceland) for the analysis. This region is remarkable in many ways and presents an interesting case study. The countries of this region have close historical, economic and cultural ties. On the other hand, these countries are closely integrated into the world and, above all, the European economy. These countries are united not only by the so-called Scandinavian model of economic and social development, which is based on the idea of the welfare state, but also by the desire of the state and society to develop national innovation systems, create and introduce new technologies, and improve processes in different sectors of the economy. All such features of the Nordic countries cannot but be reflected in the labour market. Therefore, this study analyses the relationship between labour market indicators and innovative performance in the Nordic countries.

\section{Methodology and data description}

Innovation performance is a complex phenomenon and is traditionally assessed by various indexes. This study uses the Summary Innovation Index (SII) from the EU, which consists of 27 indicators and fully reflects countries' innovative structure [7]. Among these indicators, the most significant ones can be pointed, most responsible for the differences between countries [8]. We consider the period from 2012 to 2019. During this period, the Nordic countries are listed as Innovative Leaders (Sweden (SWE), Denmark (DNK) and Finland (FIN)) and Strong Innovators (Norway (NOR) and Island (ISL)), with an index score higher than or close to the European average (Fig. 1). We can note that Sweden constantly has a high score of SII. Denmark has slightly decreased its performance in the middle of the $2010 \mathrm{~s}$ but has improved its position in 2019 as well as Finland. Since 2016, Norway demonstrates growth (a leap in 2016 is manly a statistical issue). And only in Iceland there is a decrease in innovative development in recent years.

To characterize the labour market in the Nordic countries, we use such indicators as labour force, total employment (both in the number of employees aged 20-64 and as a percentage of the total population); the number of people employed in the sectors of the economy to determine the most demanded industries; employment and unemployment among workers with different levels of education and skills to assess demand for qualified and not qualified workers. Data are retrieved from European database and OECD database. 


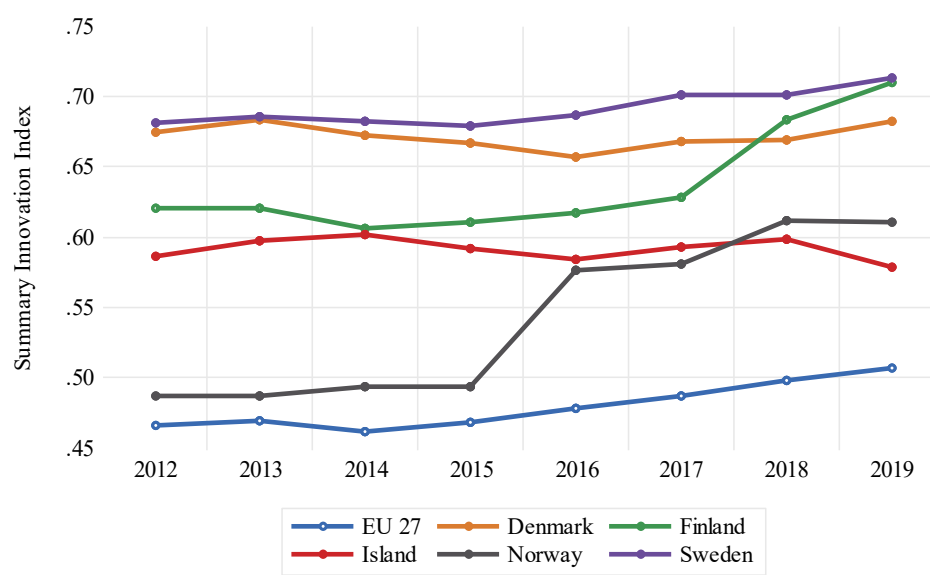

Fig.1. Innovation performance of the Nordic countries

We examine the structure of the employment by the sectors of the economy and assess employment trends. We assess the annual growth rate of employees using the OLS trend regression

$$
\ln x_{t}=\alpha+\beta t+u_{t}
$$

Here $x_{t}$ is the number of employees/labour force in a country at time $t(t=2011 \div$ 2019). $\alpha$ and $\beta$ are parameters, $u_{t}$ is an error term.

To assess the direct association between labour market indicators and innovation performance we utilize cross-correlation analysis for panel data between SII and a labour market indicator. Due to short panel (7 years from 2012 to 2019 corresponding to data available for SII and 8 years from 2011 to 2019 for labour indicators), we use only 2 lags for cross-correlation analysis as well as for the Granger causality analysis.

The cross-correlation between the two series $x$ and $y$ are given by

$$
\begin{gathered}
\operatorname{Cor}_{x y}(l)=\frac{r_{x y}(l)}{\sqrt{r_{x x}(0)} \sqrt{r_{y y}(0)}} \\
r_{x y}(l)= \begin{cases}\sum_{t=1}^{T-l} \frac{\left(x_{t}-\bar{x}\right)\left(y_{t+l}-\bar{y}\right)}{T}, & l=0,1,2 \\
\sum_{t=1}^{T+l} \frac{\left(x_{t-l}-\bar{x}\right)\left(y_{t}-\bar{y}\right)}{T}, & l=0,-1,-2\end{cases}
\end{gathered}
$$

This approach can help understand the association between the two variables in dynamics and determine the lag between innovation and labour market indicators.

However, correlation does not necessarily imply causation in any meaningful sense of that word. We use the Granger causality test to address a question of whether series $x$ causes $y \cdot y$ is said to be Granger-caused by $x$ if $x$ helps in the prediction of $y$, or equivalently if the coefficients on the lagged $x$ 's are statistically significant in the regression (3a)

$$
\begin{aligned}
& y_{t}=\alpha_{0}+\alpha_{1} y_{t-1}+\alpha_{2} y_{t-2}+\beta_{1} x_{t-1}+\beta_{2} x_{t-2}+\varepsilon_{\mathrm{t}} \\
& x_{t}=\alpha_{0}+\alpha_{1} x_{t-1}+\alpha_{2} x_{t-2}+\beta_{1} y_{t-1}+\beta_{2} y_{t-2}+\varepsilon_{\mathrm{t}}
\end{aligned}
$$

If the hypothesis $H_{0}: \beta_{1}=\beta_{2}=0$ is not rejected for the second regression (3b), it is said that $x$ is not Granger cause by $y$. It is worth noting that Granger causality measures 
precedence and information content but does not by itself indicate causality in the more common use of the term.

\section{Empirical results and discussion}

\subsection{Employment trends}

Examining the labour market indicators of the five Nordic countries, it can be noted that all countries have a high employment rate which exceeds the average rate for the OECD countries and EU countries: the employment rate of Iceland is $80.3 \%$ (it is in first place according to OECD estimates), Sweden - $75.5 \%$, Norway - 74.7\%, Denmark - 74.4\%, Finland $-72 \%$ as of 2019 .

The employment policy of the Nordic states is based on the close cooperation of employers' associations and trade unions, the main issue of which was the centralized decision on wages. Trade union participation is about $80 \%$ in Iceland and about $70 \%$ in Nordic countries. In addition, it is precisely such centralized solutions that have created the image of countries as states with high employment and a small difference in wages. Another interesting government decision was the introduction of a basic income into social security, which stimulated citizens to find employment [9].

EU 27

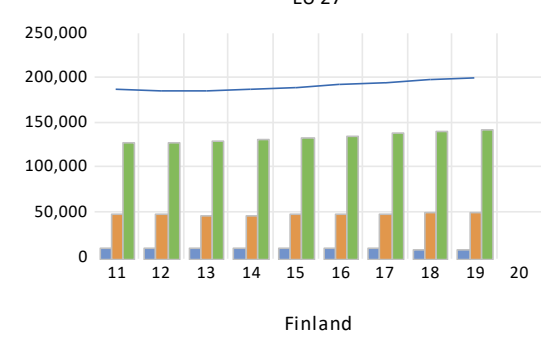

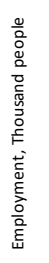

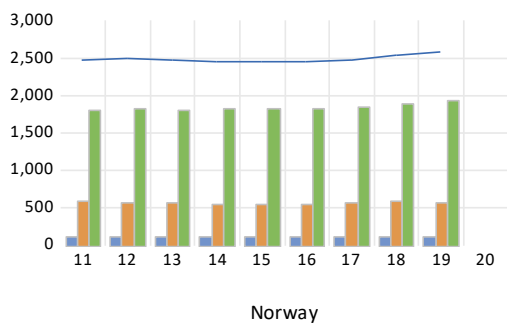

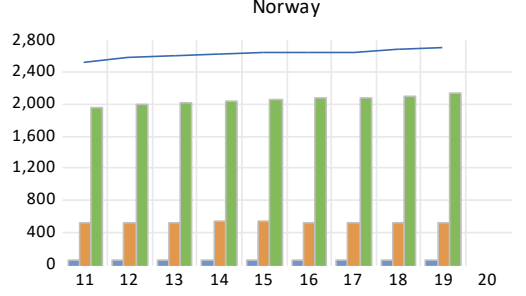
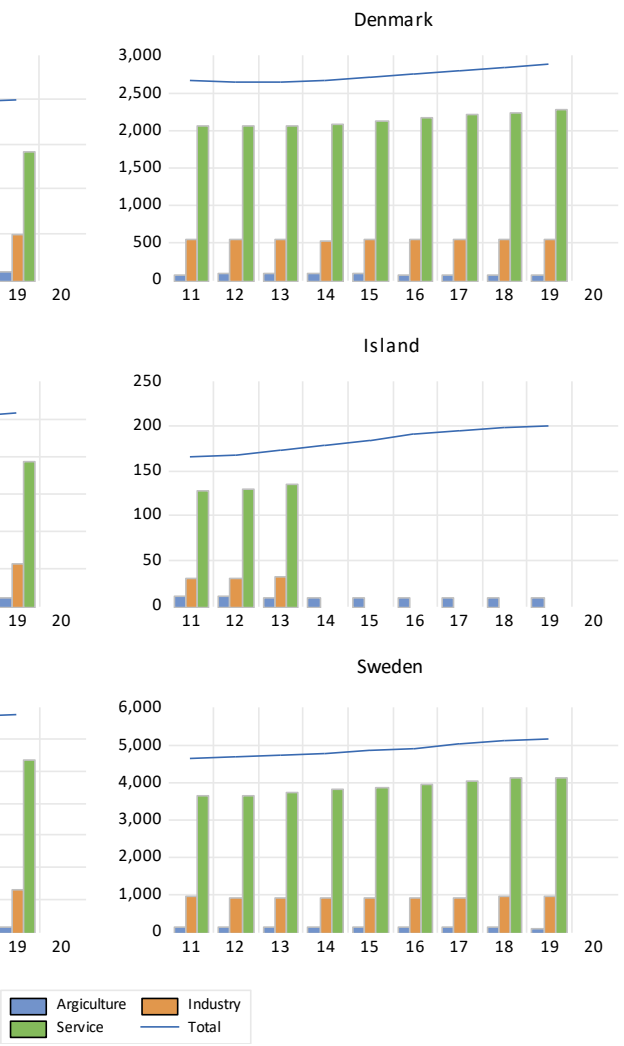

Fig.2. The structure of the employed in the sectors of the economy. Source: Eurostat database

Fig. 2 shows the structure of employed by sectors of the economy for each country and the European Union totally. These statistics demonstrate that countries have relevantly small working force mainly employed in the service sector. 
Simple charts of employment growth suggest the trend rate is very low (see Fig.2). However, Sweden and Denmark overperform other Nordic countries as well as EU in average in terms of the annual growth rate of employees.

Changes in employment breakdown by aggregate sectors are summarized in Table 1. Employment in industry (and in high-tech industry in particular) is not growing in the Nordic countries. Employment in agriculture has a negative trend although the pace is lower than in EU-27. Employment in service has a positive trend, especially in the knowledge-intensive services. Note that labour force was growing in all Nordic countries in the considered period.

In all Nordic countries the growth rate of number of employees in knowledge-intensive service is higher than the growth rate of labour force (see Table 1). We can link it with high pace of innovative development in these countries, which cause the growing demand for high-skilled workers.

Table 1. The annual average percentage change of number of employees and labour force

\begin{tabular}{|c|c|c|c|c|c|c|}
\hline & Sweden & Denmark & Finland & Norway & Island & EU-27 \\
\hline $\begin{array}{l}\text { Total } \\
\text { employment }\end{array}$ & $1.4^{* * *}$ & $1.1 * * *$ & $0.37 * * *$ & $0.7^{* * *}$ & $2.6 * * *$ & $0.98^{* * *}$ \\
\hline Industry & 0.3 & 0.02 & -0.2 & 0.0 & $\mathrm{n} / \mathrm{d}$ & $0.56^{* *}$ \\
\hline $\begin{array}{l}\text { High-tech } \\
\text { industry }\end{array}$ & 0.65 & -0.3 & -1.1 & $-2.4 * * *$ & $\mathrm{n} / \mathrm{d}$ & $1.8^{* *}$ \\
\hline Agriculture & $-0.9 *$ & $-1.1 * *$ & $-1.4 * *$ & $-0.9 *$ & $\mathrm{n} / \mathrm{d}$ & $-2.5 * * *$ \\
\hline Service & $1.7 * * *$ & $1.5 * * *$ & $0.6 * * *$ & $0.9 * * *$ & $\mathrm{n} / \mathrm{d}$ & $1.4 * * *$ \\
\hline $\begin{array}{l}\text { Knowledge- } \\
\text { intensive } \\
\text { services }\end{array}$ & $2.1 * * *$ & $0.7 * * *$ & $1.0 * * *$ & $1.0 * * *$ & $3.4 * * *$ & $1.4 * * *$ \\
\hline Labour force & $1.2 * * *$ & $0.7 * * *$ & $0.3 * * *$ & $0.7 * * *$ & $2.0 * * *$ & \\
\hline
\end{tabular}

Notes. ${ }^{* * *}$ p-value $<0.01, \mathrm{p}$-value $<0.05,{ }^{*}$ p-value $<0.10 . \mathrm{n} / \mathrm{d}-$ unavailable data

Next, we examine the average unemployment rate among different groups of working force categorized by educational attainment. The educational attainment level is coded according to the International Standard Classification of Education (ISCED). In the Fig.3 and after we use the following notations: High skill - levels 5 to 8, Middle skill- levels 3 and 4, Low skill - levels 0 to 2 (see Eurostat database for details). We calculate a simple annual average unemployment rate for each country by calculating the arithmetic mean of the unemployment rate for each of the years from 2012 till 2019. The method is acceptable because the labour force was changing very slowly in the considered period in the countries of interest.

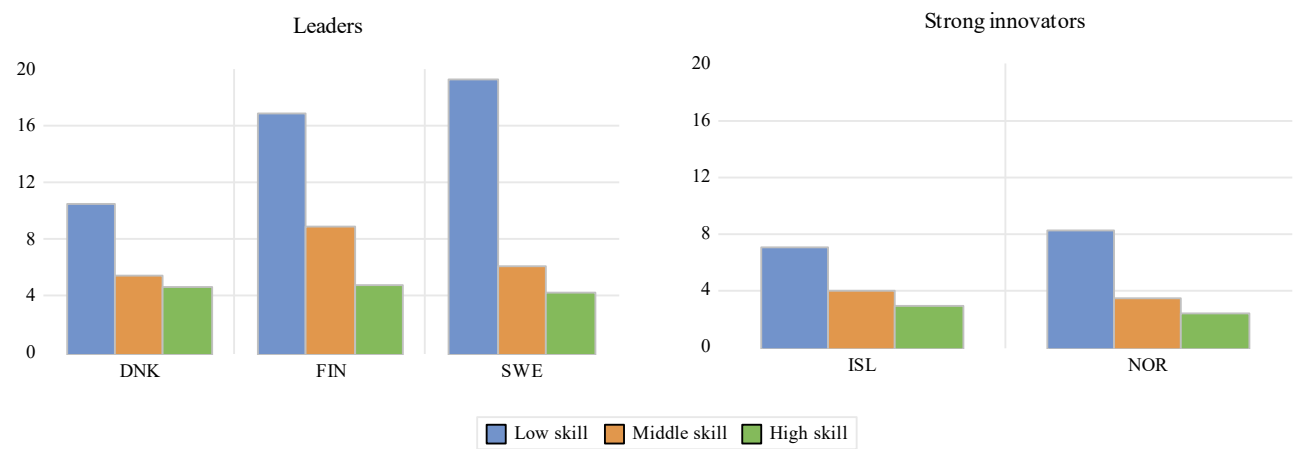

Fig.3. The simple annual average unemployment rate of different working groups 
Fig. 3 suggests that for Innovation leaders, the gap in unemployment between the groups of workers with different skill levels are rather large, and the unemployment rate among lowskilled workers is much higher than among the high-skilled. This is where the paradox arises: an increase in the level of innovative development leads to increased unemployment, at least for low-skilled workers in general. Innovative development has a somewhat negative effect on the unemployment rate. Although unemployment itself is decreasing, it has a positive simultaneous association with the index of innovative development. This is understandable, since with active innovations, new jobs are created in different industries, and this takes time. Nevertheless, new jobs cannot replace lost ones [10], therefore, states solve this problem in at least three ways: introduction of basic income [11] or its various analogues [12], a tax on robots, and a reduction in the length of the working week [13].

\subsection{Innovations vs. employment for Innovation leaders}

Let us look closer for innovation leaders (Sweden, Denmark, and Finland), whose state social policy is aimed at investing in the general welfare, but always taking into account the principles of equal opportunities for the population and the abundance of equal elements of the economic, environmental and social spheres of human life [14]. First, we consider the relationship between employment rate among people with different levels of education (different skills) and the Summary innovation index. The employment rate by the skill levels is calculated by dividing the number of employed people within the age group 20-64 years having attained a specific level of education by the total population of the same age group and with the same educational attainment level.

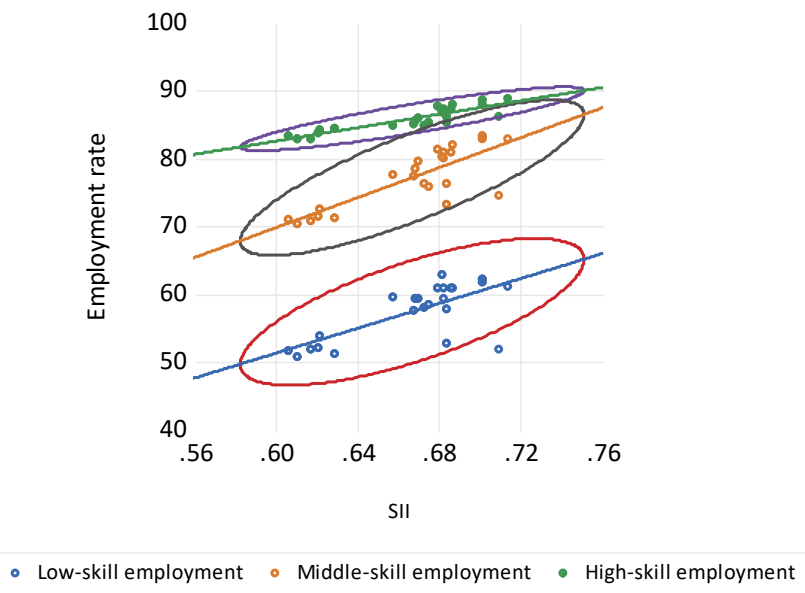

Fig. 4. The linkage between the employment rate among workers with different skill levels and the Summary innovation index for Innovation leaders.

The linkage between the employment rate and the innovation performance is very solid for highly skilled workers (the confidence ellipse is very narrow, see Fig.4.). Since innovative development requires highly qualified specialists and the higher the level of innovative development, the more qualified the employee must be. However, the slope coefficient is lower than for other skilled levels. One of the reasons is that in the Nordic countries, the employment rate of highly educated workers is very high and cannot grow at a high pace. The relationship between innovation performance and employment for middle- and lowskilled workers is not so strong, but the slope coefficient is high. The estimate shows that an increase in SII by 0.01 is associated with a more than $1 \mathrm{pp}$ increase in the employment rate for middle-skill jobs. These findings are in line with the projections of high demand for 
middle-skill jobs in future with increasing technology penetration in all sectors of the economy. On the other hand, it is a result of 'countries place an emphasis on vocational education and training, as well as maintaining a tradition of cooperative social dialogue' [15].

Table 3 shows the results of cross-correlation analysis and causal inference. This table provides the highest correlation coefficient and the corresponding lag (see formula (2)). Interpreting the results, we should consider that SII is based on indicators of previous or even the year before previous.

There is a strong negative association between the share of employment in the agriculture sector of the previous period and SII $(-0.78$ with $1=1)$. Note that Value added in the agricultural sector as per cent of GDP is about $1.5 \mathrm{pp}$ for the Nordic region.

The correlation between employment in industry and SII is modest but positive, while employment in high- and medium-tech industries is declining with innovation development. The strongest association is observed between employment in knowledge-intensive services and SII. This is a consequence of a large share of service in GDP in these countries and a policy for creating new knowledge-intensive services.

Remarkably, the employment rate is highly correlated with the innovation index for all workers breakdown by skill levels. However, the relationship is even stronger for the high skill workers. And only the high skill workers employment rate revealed to be Granger cause for innovative performance. A high level of employment among skilled workers, the intensity of spending on $R \& D$, support for innovation in society result not only in high values of the innovation development index but also in higher labour and capital productivity than in less innovative European countries [16].

Table 3. Relationship between SII and Labor market indicators

\begin{tabular}{|l|l|l|}
\hline Variable, $\mathbf{Y}$ & Cor $\left(\mathbf{S I I}_{\mathbf{t}}, \mathbf{Y}_{\mathrm{t}-\mathrm{I}}\right)$ & Granger Causality \\
\hline $\begin{array}{l}\text { Employment in agriculture, \% of } \\
\text { employment }\end{array}$ & $-0.78(\mathrm{l}=1)$ & none \\
\hline $\begin{array}{l}\text { Employment in industry, \% of } \\
\text { employment }\end{array}$ & $0.55(\mathrm{l}=0)$ & none \\
\hline $\begin{array}{l}\text { Employment in high- and } \\
\text { medium-tech industry, \% of } \\
\text { employment }\end{array}$ & $-0.58(\mathrm{l}=3)$ & none \\
\hline $\begin{array}{l}\text { Employment in service, \% of } \\
\text { employment }\end{array}$ & $0.74(\mathrm{l}=1)$ & none \\
\hline $\begin{array}{l}\text { Employment in knowledge- } \\
\text { intensive service sectors, \% of } \\
\text { employment }\end{array}$ & $0.77(\mathrm{l}=1)$ & none \\
\hline High skill employment rate & $0.89(\mathrm{l}=0)$ & Empl-> SII \\
\hline Middle skill employment rate & $0.81(\mathrm{l}=0)$ & none \\
\hline Low skill employment rate & $0.71(\mathrm{l}=0)$ & none \\
\hline
\end{tabular}

\section{Concluding remarks}

The article examines the relationship between innovative activity and labour market indicators in the Nordic countries with effective tools and instruments for development. 
Since countries are highly developed, and the service sector prevails, innovative activity has a positive relationship with employment in the service sector and a slightly negative relationship with those employed in the agricultural sector. This is understandable since innovative activity predominates in science-intensive services. The growth rate of employees in knowledge-intensive services is higher than the growth rate of total employment.

From the conducted analysis, we can conclude that innovative development does not directly affect the unemployment rate, at least when the state pays considerable efforts to reduce the negative consequences of high technologies implementation. In the more innovative Sweden, Finland and Denmark, unemployment rates for low-skilled workers are higher than in Norway or Iceland. And significantly higher than among highly and mediumskilled workers. However, the employment rate is positively related to innovation performance for all skill levels.

In order to study the relationship between innovative development, the labour market and state employment policy instruments in more detail, the pool of countries under consideration should be expanded.

\section{References}

1. S. Torp, J. Reiersen, Int. J. Environ. Res. Public Health, 17 (2020)

2. D. Ornston, Review of Policy Research, 31, 5 (2014)

3. S. S. Alam, V. Arumugam, N. G. Mohd Nor, P. Kaliappan, and L. S. Fang, Bus. Manag. Horizons, 1(1), 59 (2013)

4. V. Matyushok, V. Krasavina, A. Berezin, and J. S. García, Econ. Res. Istraživanja, 27, $1(2021)$

5. V. Y. Lyashok, T. M. Maleva, M. V. Lopatina, Economic policy, 15(4), 62 (2020)

6. J. Zysman, How revolutionary was the revolution? National responses, market transitions and global technology" (23 Stanford, CA: Stanford Business Books, 2006)

7. European Innovation Scoreboard 2020 (2020)

8. S. A. Balashova, Economics and Mathematical Method, 53(1), 21 (2017)

9. A. Volkov, World Economy and International Relations, 64(9), 48 (2020)

10. S. Aronowitz, W. DiFazio, The Jobless Future: Sci-Tech and the Dogma of Work (Minneapolis: University of Minnesota Press, 1994)

11. E. Korchak, A. Korchak, The North and the Market: Formation of the Economic Order, 3(6), 46 (2014)

12. U. Gentilini, M. Grosh, J. Rigolini, R. Yemtsov, World Bank, 337 (2020)

13. A. Hines, Foresight and STI Governance, 13(1), 19 (2019)

14. P. Frase, Verso Books, 160 (2016)

15. OECD Employment Outlook 2019, OECD (2019)

16. S. Balashova, A. Abramova, Rudn J. Econ., 29(1), 88 (2021) 